\title{
IMPLEMENTASI MODEL PEMBELAJARAN SOMATIC AUDITORY RESITASI INTERPRETASI PADA MATAKULIAH MEDIA PEMBELAJARAN MATEMATIKA
}

\author{
Mohamad Khafid Irsyadi \\ Universitas PGRI Adi Buana Kampus Blitar \\ irsyadi2008@gmail.com
}

Received 19 March 2020; revised 9 June 2020; accepted 12 June 2020.

\begin{abstract}
ABSTRAK
Tujuan penelitian ini adalah mendeskripsikan implementasi model pembelajaran Somatic Auditory Resitasi Interpretasi (SARI) pada matakuliah Media Pembelajaran Matematika. Penelitian ini merupakan penelitian tindakan kelas. Subjek penelitian ini adalah mahasiswa Prodi Pendidikan Matematika semester IV STKIP PGRI Blitar tahun akademik 2017/2018. Instrumen penelitian yang digunakan terdiri dari tes akhir siklus dan lembar observasi. Dari hasil observasi dosen pada pertemuan ke-1 didapatkan nilai 83\% dengan kriteria baik dan pertemuan ke-2 86\% dengan kriteria baik. Rata-rata aktivitas dosen adalah 84,5\% dengan kategori baik. Untuk prosentase hasil observasi aktivitas mahasiswa pada pertemuan ke-1 didapatkan nilai 83\% dengan kriteria baik dan pertemuan ke-2 85\% dengan kriteria baik. Rata-rata aktivitas mahasiswa $84 \%$ dengan kategori baik. Berdasarkan hasil tes akhir siklus, dari 20 mahasiswa Prodi Pendidikan Matematika semester IV STKIP PGRI Blitar diperoleh 17 mahasiswa telah tuntas belajar dan sisanya 3 mahasiswa tidak tuntas belajar. Hal ini sesuai dengan kriteria keberhasilan yaitu $\geq 75 \%$ dari jumlah mahasiswa keseluruhan yang mencapai taraf nilai $\geq 75$ sesuai dengan ketuntasan individu yang tetapkan. Langkah-langkah model pembelajaran somatic, auditory, resitasi, interpretasi yaitu (a) Somatic adalah mahasiswa diminta untuk belajar dengan berbuat dan bergerak, (b) Auditory adalah belajar dengan berbicara dan mendengar, (c) Resitasi adalah penugasan. Penugasan digunakan untuk mengukur sejauh mana tingkat kefahaman mahasiswa, (d) Interpretasi adalah penarikan kesimpulan.
\end{abstract}

Kata kunci: implementasi, Somatic Auditory Resitasi Interpretasi (SARI), media pembelajaran matematika.

\begin{abstract}
The purpose of this study is to describe the implementation of the Somatic Auditory Recitation Interpretation (SARI) learning model of Mathematics Learning Media subjects. This research is a classroom action research. The subjects of this study are students of the fourth semester, Mathematics Education Department, academic year 2017/2018 at STKIP PGRI Blitar. The research instrument consisted of the end of cycle test and observation sheet. From the
\end{abstract}




\section{Mohamad Khafid Irsyadi}

lecturers observations at the 1st meeting obtained $83 \%$ with good criteria and the 2nd meeting $86 \%$ with good criteria. The average lecturer activity is $84.5 \%$ with a good category. For the percentage of observations of student activity at the 1st meeting values obtained $83 \%$ with good criteria and the second meeting $85 \%$ with good criteria. The average student activity is $84 \%$ with a good category. Based on the end cycle test results, from 20 students, 17 students have completed their studies and the remaining 3 students did not complete their studies. This is in accordance with the criteria for success, which is $\geq 75 \%$ of the total number of students who reach a grade of $\geq$ 75 based on the specified individual completeness. The steps of the somatic, auditory, recitation, interpretation learning model are (a) Somatic is the student asked to learn by doing and moving, (b) Auditory is learning by speaking and listening, (c) Recitation is an assignment. Assignments are used to measure the extent of student understanding, (d) Interpretation is drawing conclusions.

Keywords: implementation, Somatic Auditory Recitation Interpretation (SARI), mathematics learning media.

\section{PENDAHULUAN}

Slameto (2010) menyatakan belajar adalah suatu proses usaha yang dilakukan seseorang untuk memperoleh suatu perubahan tingkah laku yang baru secara keseluruhan, sebagai hasil pengalamannya sendiri dalam interaksi dengan lingkungannya. Dalam implementasinya, kegiatan yang dilakukan oleh mahasiswa itu yang dimaksud belajar, sedangkan mengajar merupakan kegiatan yang dilakukan oleh dosen. Dosen juga bertugas untuk mendorong dan membimbing serta memberikan fasilitas belajar bagi mahasiswa agar dapat mencapai pendidikan, karena diketahui bahwa dalam keseluruhan proses pendidikan di sekolah kegiatan pembelajaran merupakan kegiatan yang paling utama. Keberhasilan pencapaian tujuan pendidikan banyak tergantung pada bagaimana proses belajar yang dialami oleh mahasiswa.

Dalam proses pembelajaran di kampus mahasiswa dituntut aktif dalam menggali potensi, tetapi peran dosen juga tidak kalah pentingnya dalam mencapai tujuan pendidikan. Dosen harus menciptakan kondisi kelas dimana mahasiswa tidak merasa bosan dan jenuh. Selain itu pelajaran yang diterima tidak terkesan membosankan tetapi pelajaran dapat terkesan menarik sehingga meningkatkan minat dan hasil belajar mahasiswa. Untuk mencapai tujuan tersebut maka dosen harus menguasai materi sebagai tanggung jawabnya, dan menguasai dengan baik tentang teknik dan metode belajar. Berdasarkan hasil observasi awal pada bulan Maret 2018 terdapat beberapa permasalahan dapat diidentifikasikan sebagai 
berikut: (1) Hanya beberapa mahasiswa yang aktif dalam proses perkuliahan, sementara mahasiswa yang lain masih bersifat pasif; (2) Kelengkapan bahan ajar yang digunakan dalam perkuliahan sangat terbatas; (3) Mahasiswa kesulitan dalam memahami terkait materi pemanfaatan media pembelajaran matematika. Dari kekurangan hasil obserrvasi awal tersebut, yang dapat mengatasi permasalahan salah satunya dengan cara menerapkan model pembelajaran Somatic Auditory Resitasi Interpretasi (SARI).

Menurut Shoimin (2014) menjelaskan "model pembelajaran SARI adalah pembelajaran yang menekankan bahawa belajar memanfaatkan semua alat indera yang dimiliki mahasiswa. Somatic (belajar dengan berbuat dan bergerak), auditory (belajar dengan berbicara dan mendengar)". Sedangkan menurut Mukrima (2014) menjelaskan "resitasi adalah suatu metode pengajaran dengan mengharuskan mahasiswa membuat resume dengan kalimat sendiri”. Interpretasi dalam Kamus Besar Bahasa Indonesia (KBBI) diartikan sebagai pemberian kesan, pendapat, tafsiran, atau pandangan teoritis terhadap sesuatu. Sedangkan proses penafsiran yang berlangsung atau hasil dari proses disebut dengan interprestasi. Bagian dari presentasi atau penggambaran informasi yang diubah merupakan suatu interpretasi, dengan tujuan menyesuaikan kumpulan simbol spesifik.

Terdapat beberapa penelitian yang pernah dilakukan tentang model pembelajaran Somatic Auditory Resitasi Interpretasi. Berdasarkan penelitian yang telah dilakukan oleh Ginting \& Amir (2012) berjudul "Penerapan Model Pembelajaran SAVI (Somatic Auditori Visual dan Intelektual) Berbantuan Media Komputer untuk Meningkatkan Kualitas Pembelajaran Kimia Fisika II" menunjukkan bahwa secara umum model pembelajaran SAVI dapat meningkatkan kualitas pembelajaran Mata Kuliah Kimia Fisik II di Program Studi Pendidikan Kimia JPMIPA FKIP tahun ajaran 2011/2012. Hasil belajar siswa secara umum meningkat. Walaupun terjadi fluktuasi akibat perbedaan tingkat kesulitan materi yang diajarkan. Keaktifan mahasiswa meningkat dari $70 \%$ hingga 90\% dalam pembelajaran menggunakan model SAVI berbantuan media berbasis komputer. Berdasarkan uraian tersebut dilakukan penelitian tentang penerapan model pembelajaran Somatic Auditory Resitasi Interpretasi (SARI) pada 


\section{Mohamad Khafid Irsyadi}

matakuliah Media Pembelajaran Matematika untuk perbaikan perkuliahan di Program Studi Pendidikan Matematika STKIP PGRI Blitar ke depan.

\section{METODE PENELITIAN}

Penelitian Tindakan Kelas (PTK) merupakan jenis penelitian yang digunakan. Subjek penelitian ini adalah mahasiswa Prodi Pendidikan Matematika STKIP PGRI Blitar semester IV yang berjumlah 20 mahasiswa. Pihak yang terlibat dalam penelitian tindakan kelas yaitu peneliti selaku perencana, pelaksana, pengamat, pengevaluasi dan penyusun laporan.

Prosedur penelitian yang digunakan dalam mengimplementasikan model pembelajaran kooperatif tipe Somatic Auditory Resitasi Interpretasi adalah menggunakan penelitian tindakan kelas dengan mengadopsi model spiral dari Kemmis dan Mc Taggart (Arikunto, 2006a). Dalam perencanaanya, Kemmis menggunakan sistem spriral refleksi diri yang dimulai dengan rencana, tindakan, pengamatan, refleksi, dan perencanaan kembali yang merupakan dasar untuk pemecahan permasalahan. Menurut Kemmis dan Mc Taggart, penelitian tindakan kelas dilakukan melalui proses yang dinamis dan komplementari yang terdiri dari empat "momentum" esensial, yaitu (1) perencanaan (plan); (2) tindakan (act); (3) pengamatan (observe); (4) refleksi (reflect).

Instrumen penelitian menggunakan lembar tes dan lembar observasi. Tes digunakan untuk mengumpulkan informasi tentang pemahaman mahasiswa terhadap materi teknik merancang media pembelajaran. Tes dilakukan pada akhir siklus untuk melihat kemajuan mahasiswa dalam mengikuti pembelajaran, serta digunakan untuk mengukur keberhasilan belajar mahasiswa dalam periode waktu tersebut. Bentuk tes yang digunakan dalam penelitian ini adalah bentuk tes uraian, karena dengan tes uraian dapat mempermudah peneliti dalam mengidentifikasi kesulitan-kesulitan yang dialami mahasiswa dalam memahami materi teknik merancang media pembelajaran. "Tes adalah alat atau prosedur yang digunakan untuk mengetahui atau mengukur sesuatu dalam suasana, dengan cara dan aturanaturan yang sudah ditentukan. Dalam pengerjaan tes, harus sesuai dengan petunjuk yang diberikan, misal melingkari salah satu huruf di depan pilihan jawaban, menerangkan, mencoret jawaban yang salah, melakukan tugas atau 
suruhan, menjawab secara lisan dan sebagainya" (Arikunto, 2006b). Observasi berfungsi untuk mengamati aktivitas dosen dan mahasiswa untuk memperoleh data saat proses perkuliahan berlangsung yang dapat memperkuat data hasil penelitian. Lembar observasi terdapat dua macam yakni lembar observasi aktivitas dosen dan observasi aktivitas mahasiswa. Analisis data hasil observasi menggunakan analisis penskoran seperti yang terdapat pada lembar observasi. Pengamatan atau observasi adalah kegiatan pengamatan (pengambilan data) untuk memotret seberapa jauh efek tindakan yang telah mencapai sasaran (Kunandar, 2008).

Teknik analisa data digunakan untuk mengetahui penerapan mahasiswa dalam pembelajaran matematika setelah menerapkan model pembelajaran Somatic Auditory Resitasi Interpretasi pada materi teknik merancang media pembelajaran. Seorang mahasiswa dikatakan mencapai ketuntasan tes akhir siklus apabila mencapai taraf penguasaan minimal $75 \%$ atau dengan nilai 75. Mahasiswa dikatakan tuntas jika ketuntasan individu $\geq 75$, dengan rumus ketuntasan individu diberikan,

$$
\text { Ketuntasan individu }=\frac{\text { jumlah perolehan skor siswa }}{\text { nilai maksimal }} \times 100 \%
$$

Ketuntasan klasikal disebut telah berhasil, apabila paling sedikit 75\% dari jumlah mahasiswa dalam satu kelas tersebut telah mencapai ketuntasan individu.

$$
\text { Ketuntasan klasikal }=\frac{\text { jumlah siswa yang mencapai ketuntasan }}{\text { total siswa di kelas }} \times 100 \%
$$

Dalam penelitian ini dibuat dua lembar observasi, yaitu lembar observasi mahasiswa dan lembar observasi dosen yang masing-masing berpedoman sebagai berikut,

$$
\text { Persentase skor rata-rata }(\mathrm{NR})=\frac{\text { skor yang didapat }}{\text { skor maksimal }} \times 100 \%
$$

dengan kriteria seperti pada Tabel 1.

Tabel 1. Kriteria Penilaian Observasi Aktivitas Dosen dan Mahasiswa

\begin{tabular}{cc}
\hline Presentase Ketuntasan & Katagori \\
\hline $90 \% \leq P_{O} \leq 100 \%$ & Sangat baik \\
$80 \% \leq P_{O}<90 \%$ & Baik \\
$70 \% \leq P_{O}<80 \%$ & Cukup baik \\
$60 \% \leq P_{O}<70 \%$ & Kurang \\
$0 \% \leq P_{O}<60 \%$ & Sangat Kurang \\
\hline
\end{tabular}




\section{HASIL PENELITIAN DAN PEMBAHASAN}

Perolehan hasil tes akhir siklus adalah sebanyak 17 dari 20 mahasiswa telah mencapai Kriteria Ketuntasan Minimum (KKM) yaitu $\geq 75$, sedangkan 3 mahasiswa lainnya belum mencapai KKM. Berdasarkan hal tersebut, ketuntasan klasikal diperoleh sebesar $85 \%$ sehingga secara klasikal dikatakan "tuntas" karena sudah $\geq 75 \%$ mahasiswa telah mencapai ketuntasan individu. Hasil tes akhir siklus disajikan dalam Tabel 2.

Tabel 2. Hasil Tes Akhir Siklus

\begin{tabular}{lc}
\hline \multicolumn{1}{c}{ Keterangan } & Hasil Tes Akhir Siklus \\
\hline Jumlah mahasiswa tuntas & 17 orang \\
Jumlah mahasiswa tidak tuntas & 3 orang \\
Prosentase mahasiswa yang tuntas & $85 \%$ \\
Prosentase mahasiswa yang tidak tuntas & $15 \%$ \\
\hline
\end{tabular}

Hasil observasi dosen pada pertemuan ke-1 didapatkan nilai $83 \%$ dengan kriteria baik dan pertemuan ke-2 adalah $86 \%$ dengan kriteria baik. Rata-rata aktivitas dosen adalah 84,5\% dengan kategori baik. Untuk prosentase hasil observasi aktivitas mahasiswa, pada pertemuan ke-1 didapatkan nilai 83\% dengan kriteria baik dan pertemuan ke-2 sebesar $85 \%$ dengan kriteria baik. Rata-rata aktivitas mahasiswa adalah $84 \%$ dengan kategori baik. Hasil observasi aktivitas dosen dan mahasiswa disajikan dalam Tabel 3.

Tabel 3. Hasil Observasi Aktivitas Dosen dan Mahasiswa

\begin{tabular}{|c|c|c|c|c|}
\hline \multirow[b]{2}{*}{ Observasi } & \multicolumn{2}{|c|}{ Hasil } & \multirow{2}{*}{$\begin{array}{c}\text { Rata- } \\
\text { rata }\end{array}$} & \multirow[b]{2}{*}{ Kriteria } \\
\hline & $\begin{array}{c}\text { Pertemuan } \\
\text { Ke-1 }\end{array}$ & $\begin{array}{c}\text { Pertemuan } \\
\text { Ke-2 }\end{array}$ & & \\
\hline Observasi aktivitas dosen & $83 \%$ & $86 \%$ & $84,5 \%$ & Baik \\
\hline Observasi aktivitas mahasiswa & $83 \%$ & $85 \%$ & $84 \%$ & Baik \\
\hline
\end{tabular}

Dari hasil tes akhir siklus I, hasil observasi aktivitas dosen maupun aktivitas mahasiswa adalah baik. Hasil pengerjaan lembar aktivitas mahasiswa pada setiap pertemuan juga diperoleh hasil $\geq 75$, artinya penelitian ini sudah memenuhi kriteria keberhasilan.

Dalam proses penelitian, digunakan model pembelajaran Somatic Auditory Resitasi Interpretasi (SARI) untuk membahas materi teknik merancang media pembelajaran. Model pembelajaran SARI ini diharapkan dapat melatih mahasiswa 
untuk berpikir cepat dan tepat, mendorong mahasiswa untuk belajar mengerjakan soal dengan jawaban acak terhadap materi teknik merancang media pembelajaran. Langkah-langkah dalam implementasi model pembelajaran SARI yang telah dilakukan dipaparkan satu-persatu.

Pada awal pembelajaran, dosen mengucapkan salam dan memeriksa kehadiran mahasiswa, kemudian menyampaikan tujuan pembelajaran, serta memotivasi mahasiswa untuk terlibat aktif dalam pembelajaran yang berkaitan pada materi teknik merancang media pembelajaran. Motivasi pada tahap ini digunakan untuk memberi dorongan dan semangat kepada mahasiswa untuk memahami dan memaknai pembelajaran pada hari itu serta tetap fokus dalam memperhatikan pembelajaran. Hal tersebut sesuai dengan pendapat Rusmono (2012) yang mengatakan "motivasi dapat menarik mahasiswa untuk tetap mempertahankan perhatian lewat instruksi”.

Tahap somatic (belajar dengan berbuat dan bergerak). Pada tahap pertama ini, dosen membentuk kelompok yang beranggotakan 2-3 orang berdasarkan nilai dari survei awal. Pembagian kelompok berdasarkan nilai dilakukan oleh dosen supaya mahasiswa dapat berbagi kemampuan, yaitu antara mahasiswa berkemampuan tinggi dengan mahasiswa berkemampuan sedang dan rendah. Menurut Hamdani (2011) mengatakan bahwa "manfaat pembentukan kelompok secara heterogen adalah untuk melatih mahasiswa menerima perbedaan cara bekerja dengan teman yang berbeda latar belakangnya". Dosen memberikan contoh teknik merancang media pembelajaran untuk mengatasi keterbatasan pengalaman yang dimiliki oleh mahasiswa, proses pembelajaran menjadi lebih jelas dan menarik, dapat menanamkan konsep dasar yang benar, konkret dan realistis, membangkitkan keinginan dan minat baru, serta memberikan pengalaman menyeluruh dari yang konkret sampai dengan abstrak. Hal ini sesui dengan pendapat Kempt dan Dayton (dalam Daryanto, 2011) menjelaskan manfaat alat peraga adalah "proses pembelajaran menjadi lebih jelas dan menarik, proses pembelajaran menjadi lebih interaktif, meningkatkan kualitas hasil belajar mahasiswa". Dosen mengarahkan mahasiswa untuk mengerjakan soal-soal pada bahan ajar sesuai dengan instruksi yang telah ditentukan dalam bahan ajar. Dosen juga menghimbau untuk saling mengajari antar anggota kelompok yang belum 


\section{Mohamad Khafid Irsyadi}

paham. Pada pertemuan pertama dalam penerapan model pembelajaran SARI dibahas tentang teknik merancang media pembelajaran.

Tahap auditory (belajar dengan mendengarkan dan menanggapi). Setelah semua mahasiswa selesai mengerjakan, dosen meminta salah satu perwakilan kelompok untuk mempresentasikan hasil diskusinya di depan kelas. Auditory atau belajar dengan berbicara dan mendengar bermakna bahwa belajar haruslah melalui mendengar, menyimak, berbicara, presentasi, argumentasi, mengemukakan pendapat, dan menanggapi (Shoimin, 2014).

Tahap resitasi (penugasan). Dosen meminta masing-masing individu untuk menyelesaikan soal-soal dalam bahan ajar dan menuliskan jawabannya dalam lembar jawab yang disediakan oleh dosen. Penugasan atau evaluasi dibutuhkan untuk mengukur kemampuan setiap individu dari pembelajaran yang telah di lakukan. Menurut Rusmono (2012) mengatakan bahwa "evaluasi dapat memberikan umpan balik yang membangun secara verbal dan tertulis terhadap individu dan memaksimalkan tanggung jawab individu". Selain itu, Mukrima (2014) menjelaskan "kelebihan metode penugasan adalah pengetahuan yang diperoleh peserta didik dari hasil belajar sendiri akan dapat diingat lebih lama, serta peserta didik memiliki peluang untuk meningkatkan keberanian, inisiatif, bertanggung jawab, dan mandiri”.

Tahap interpretasi (penarikan kesimpulan). Sebelum pembelajaran diakhiri dosen memberikan kesempatan kepada mahasiswa untuk menanyakan hal-hal yang belum dipahami tentang materi yang telah diajarkan, tahap ini berguna agar mahasiswa benar-benar paham. Hal ini sesuai yang terdapat dalam KBBI yaitu "interpretasi diartikan sebagai pemberian kesan, pendapat, tafsiran, atau pandangan teoritis terhadap sesuatu" (Setiawan, 2011). Kemudian dosen bersama mahasiswa membuat kesimpulan tentang materi pembelajaran yang telah di pelajari. Dosen meminta mahasiswa untuk menuliskan kesimpulan.

Berdasarkan uraian tersebut, kegiatan pembelajaran yang dilaksanakan dengan menerapkan model pembelajaran SARI diharapkan dapat menjadikan mahasiswa berperan aktif dan lebih memahami materi teknik merancang media pembelajaran karena mahasiswa tidak hanya mendengarkan ceramah dari dosen saja. Namun mahasiswa juga memperagakan untuk menggunakan media yang 
telah diberikan oleh dosen. Beberapa temuan hasil penelitian disajikan pada Tabel 4.

Tabel 4. Temuan Hasil Penelitian

\begin{tabular}{ccl}
\hline No. & Temuan & \multicolumn{1}{c}{ Uraian } \\
\hline 1. & Peneliti & $\begin{array}{l}\text { Mahasiswa kurang teliti dalam membuat rancangan } \\
\text { a. Dosen harus menegur dan memotivasi mahasiswa } \\
\text { b. Mahasiswa masih malu untuk bertanya materi yang } \\
\text { kurang dipahami }\end{array}$ \\
3. & Observer 1 & $\begin{array}{l}\text { Mahasiswa kurang aktif dalam pembelajaran, namun } \\
\text { dalam pembelajaran sudah dibentuk kelompok sehingga } \\
\text { mahasiswa mau mengerjakan }\end{array}$ \\
\hline
\end{tabular}

\section{SIMPULAN}

Berdasarkan pembahasan dalam penelitian ini, dapat disimpulkan bahwa implementasi model pembelajaran Somatic Auditory Resitasi Interpretasi (SARI) pada matakuliah Media Pembelajaran Matematika dapat memenuhi kriteria keberhasilan penelitian. Penerapan model pembelajaran SARI pada materi teknik merancang media pembelajaran sebagai berikut, (1) Somatic adalah mahasiswa diminta untuk belajar dengan berbuat dan bergerak. Pada awal pembelajaran, dosen memberikan contoh teknik merancang media pembelajaran. Dari contoh tersebut, mahasiswa di minta untuk merancang media pembelajaran sesuai petunjuk pada bahan ajar; (2) Auditory adalah belajar dengan berbicara dan mendengar. Pada tahap ini, dosen meminta masing-masing perwakilan kelompok untuk mempresentasikan dan menunjukkan hasil rancangan media pembelajaran ke mahasiswa yang lain untuk dapat mendengarkan dan memberikan pendapat apabila terdapat perbedaan jawaban dalam menyelesaikan tugas kelompok tersebut; (3) Resitasi adalah penugasan. Penugasan digunakan untuk mengukur tingkat pemahaman mahasiswa dalam melaksanakan pembelajaran. Pada tahap ini dosen memberikan soal-soal yang ada pada bahan ajar yang diselesaikan secara berkelompok; (4) Interpretasi adalah penarikan kesimpulan. Dosen memberikan kesempatan kepada mahasiswa untuk menuliskan kesimpulan dari apa saja yang telah mahasiswa dapatkan dari pembelajaran yang telah dilaksanakan. Serta pada akhir pembelajaran dosen memberikan ringkasan materi kepada mahasiswa sebagai penguatan materi yang telah dipelajari. Hasil pengerjaan lembar aktivitas 


\section{Mohamad Khafid Irsyadi}

mahasiswa mencapai nilai $\geq 75$, sehingga semua kelompok dapat dikatakan "tuntas". Hasil observasi aktivitas dosen pada pertemuan ke-1 didapatkan nilai $83 \%$ dengan kriteria baik dan pertemuan ke-2 sebesar $86 \%$ dengan kriteria baik. Rata-rata aktivitas dosen adalah 84,5\% dengan kategori baik. Untuk observasi aktivitas mahasiswa pada pertemuan ke-1 didapatkan nilai $83 \%$ dengan kriteria baik dan pertemuan ke-2 85\% dengan kriteria baik. Rata-rata aktivitas mahasiswa adalah 84\% dengan kategori baik. Berdasarkan hasil tes akhir siklus, dari 20 mahasiswa Prodi Pendidikan Matematika semester IV STKIP PGRI Blitar diperoleh 17 mahasiswa telah tuntas belajar dan sisanya 3 mahasiswa tidak tuntas belajar. Hal ini sesuai dengan kriteria keberhasilan yaitu $\geq 75 \%$ dari jumlah mahasiswa keseluruhan yang mencapai taraf nilai $\geq 75$.

\section{DAFTAR PUSTAKA}

Ginting, S. M., \& Amir, H. (2012). Penerapan model pembelajaran somatis auditor visual dan intelektual (SAVI) berbantuan media computer untuk meningkatkan kualitas pembelajaran kimia fisika. Jurnal Exacta, 10(1), 98105.

Arikunto, S. (2006a). Penelitian tindakan kelas. Jakarta: PT. Bumi Aksara.

Arikunto, S. (2006b). Prosedur penelitian suatu pendekatan praktik. Jakarta: PT. Bumi Aksara.

Daryanto. (2011). Media pembelajaran. Bandung: PT Sarana Tutorial Nurani Sejahtera.

Hamdani. (2011). Strategi belajar mengajar. Bandung: Pustaka Setia.

Kunandar. (2008). Penelitian tindakan kelas. Jakarta: PT. Raja Grafindo Persada.

Mukrima, S. (2014). Metode belajar dan pembelajaran. Bandung: Bumi Siliwangi.

Rusmono. (2012). Strategi pembelajaran problem based learning. Bogor: Ghalia Indonesia.

Setiawan, H. (2011). Kamus bahasa Indonesia. Surabaya: Karya Gemilang Utama.

Shoimin, A. (2014). Model pembelajaran inovatif dalam kurikulum 2013. Yogyakarta: Ar-Ruzz Media.

Slameto. (2010). Belajar dan faktor-faktor yang mempengaruhi. Jakarta: PT Rineka Cipta. 